logos_i_ethos_2020_1_(53), s. 7-29

DOI: http://dx.doi.org/10.15633/lie.3687

Maciej Manikowski

https://orcid.org/0000-0002-8278-5475

Uniwersytet Wrocławski

\title{
Sapientia - Scientia - Metafisica. Uwagi na marginesie tekstu Stanisława Kamińskiego o mądrości
}

Mądrość była, i jest, pojmowana na różne sposoby. Trzeba się dziś zastanowić, czy myślenie o mądrości jest ciągle aktualne, i czy dziś, oprócz podejścia praktycznego, nadal odwołującego się do mądrości rozumianej jako - przykładowo - mądrość życiowa, ma sens teoretyczne podejście do mądrości. Można takie pytanie sformułować jeszcze inaczej: czy dziś w filozofii, choć nie tylko, mamy okazję do stawiania sobie pytań zasadniczych i szukania na te pytanie właściwych odpowiedzi?

W tradycji myślenia europejskiego, głównie zachodniego, odwołujemy się do obrazów biblijnych. Spotykamy tam Mądrość, która zaprasza na ucztę wszystkich ludzi (Prz 9, 1-6), Mądrość, która wychwalając siebie samą, mówi „wyszłam z ust Najwyższego” (Syr 24, 3), Mądrość, która jest Towarzyszką Stwórcy w Jego działalności stwórczej (Prz 8, 22-31), czy też Mądrość mówiącą o sobie, że jest „duchem miłującym ludzi” (Mdr 1, 6). W tradycji teologicznego myślenia chrześcijańskiego utożsamiamy Mądrość z Synem Bożym, z Jezusem Chrystusem. Te tradycje, połączone $z$ tradycjami myślenia żydowskiego i muzułmańskiego, jak 
również z myśleniem starożytnych Greków, stworzyły specyficzną perspektywę myślenia o Mądrości, zarówno pisanej wielką, jak i małą literą.

Choć to biblijne źródło mogłoby sugerować jedynie teologiczne czy religijne pojmowanie mądrości, w tradycji myślenia europejskiego spotykamy bardzo wielu filozofów, którzy przedmiotem swej refleksji uczynili mądrość jako taką. Jednak ich podejście do mądrości jest znamienne, bowiem nie tylko uważają ją za cel wszelkich dociekań teoretycznych, ale przede wszystkim za koronę poznania metafizycznego. Ukazanie właśnie tego aspektu, mądrości jako celu i ukoronowania poznania metafizycznego, chciałbym uczynić głównym motywem tego tekstu, a swoistą drogą będą rozważania o mądrości poczynione w tekście polskiego filozofa, metodologa filozofii i teologa, ks. Stanisława Kamińskiego (1919-1986) ${ }^{1}$. Nie jest to jedynie zreferowanie poglądów Kamińskiego, gdyż jego tekst o mądrości należy traktować jako propedeutyczny, lecz próba pokazania, jak rozważania o mądrości wpływają na rozumienie poznania metafizycznego.

Ponieważ Kamiński jest wychowankiem lubelskiej Alma Mater, to prócz tradycji polskiej szkoły logiczno-metodologicznej, tradycji metodologicznej i metafilozoficznej, jest również dziedzicem lubelskiej szkoły filozoficznej (jest przecież i jej współtwórcą), twórczo odczytującej i interpretującej myśl Tomasza z Akwinu i jego uczniów. W jego myśleniu o mądrości głównym źródłem inspiracji jest francuski tomista Jacques Maritain, do którego na początku swego tekstu wprost się odwołuje, ale również i myśl filozoficzna Akwinaty, twórczo odczytująca myśl Arystotelesa. Z tego też powodu, zanim przejdę do prezentacji poglądów Kamińskiego, przedstawię krótko źródłowe dla jego myśli inspiracje płynące z filozofii Tomasza i Maritaina.

1 S. Kamiński, Nauka i filozofia a mądrość, w: S. Kamiński, Jak filozofować? Studia z metodologii filozofii klasycznej, red. T. Szubka, Lublin 1989, s. 55-61. Artykuł ten będzie dla mnie podstawą przy opracowywaniu zagadnień mądrości w myśli S. Kamińskiego. Inne jego teksty podejmują zagadnienie mądrości przy okazji omawiania innych zagadnień filozoficznych i znajdują się $\mathrm{w}$ pięciotomowym wyborze jego prac metodologicznych i filozoficznych. 


\section{1. Źródła Kamińskiego myślenia o mądrości}

Źródła myślenia danego filozofa można zawsze podzielić na bezpośrednie i pośrednie, czyli na te, które cytuje on wprost, jak i te, na które powołuje się on jedynie domyślnie. Można też mówić o źródłach, które są szeroko pojmowaną inspiracją, które dają się wskazać w toku myślenia czy argumentacji, choć nie znajdziemy ich w czytanych tekstach. W przypadku analizowanego tekstu Kamińskiego źródłem bezpośrednim jest książka Nauka i mądrość Maritaina ${ }^{2}$,́ródłem pośrednim jest myśl Tomasza, natomiast źródłem z szeroko pojmowanej inspiracji jest także myśl tomistyczna, dokonująca interpretacji filozofii i teologii Akwinaty.

Akwinata, korzystając twórczo z myśli Arystotelesa, jak również z myślicieli arabskich, żydowskich i chrześcijańskich, podejmując problem mądrości, umieszcza go w szerszym kontekście filozoficznym, odwołując się z jednej strony do aspektu teoretycznego i praktycznego, a z drugiej do posadowienia mądrości w jej relacji do rozumienia i wiedzy. W obu przypadkach dla Tomasza mądrość zawsze będzie pewną sprawnością ludzkiego intelektu, bowiem w tym wypadku podejście Akwinaty jest filozoficzne.

We fragmencie z Sumy teologicznej można dostrzec odpowiedź na pytanie o miejsce mądrości w ludzkim systemie poznawania. Dopiero po rozstrzygnięciu tego zagadnienia pojawi się odpowiedź na pytanie: czym jest mądrość. We wspomnianym fragmencie czytamy: „Człowiek natomiast odpowiednio do różnych przedmiotów poznania ma różne rodzaje poznania. Mówi się, że ma rozumienie, gdy poznaje zasady; a wiedzę, gdy poznaje wnioski; mądrość, kiedy poznaje najwyższą przyczynę; radę zaś czy roztropność, gdy poznaje przedmioty działania. Bóg wszystko to poznaje jednym i prostym poznaniem"3. To, co dla Boga

2 J. Maritain, Nauka i mądrość, tłum. M. Reutt, Warszawa 2004. Jest to reprint wydania z 1936 roku. Podstawą dla książki Maritaina były jego wykłady wygłoszone w rzymskim Angelicum w roku 1934, a wydane w paryskim wydawnictwie Labergerie w 1936 roku.

3 Tomasz z Akwinu, STh, I, q.14, a.1. Polskie tłumaczenie za: Tomasz z Akwinu, Traktat o Bogu. Summa teologii, kwestie 1-26, tłum. G. Kurylewicz, Z. Nerczuk, M. Olszewski, Kraków 1999, s. 201-202. 
jest dostępne w jednym i prostym akcie poznania, człowiekowi jest dane w wyniku pewnej drogi poznawczej. Prowadzi ona od rozumowania, w którym odkrywamy zasady, poprzez wiedzę, która jest znajomością wniosków wynikających z poznanych zasad, ku mądrości, która jest znajomością czy poznaniem najwyższej przyczyny. Ta najwyższa przyczyna to na poziomie teologii Bóg, a na poziomie metafizyki - pierwsza przyczyna. Choć nie ma tego powiedzianego tutaj wprost, takie podejście trzy wymienione przez Tomasza etapy - jest myśleniem teoretycznym, bowiem przedmioty związane $\mathrm{z}$ działaniem człowieka poznajemy inaczej, poprzez to, co Tomasz nazywa radą czy też roztropnością. Mądrość zatem to najwyższy poziom czy aspekt myślenia teoretycznego, w którym człowiek intelektualnie dociera do pierwszej przyczyny. I trzeba powiedzieć wprost: chodzi o realne poznanie pierwszej przyczyny, a nie tylko jej intelektualne skonstruowanie.

Odwołując się do Metafizyki Arystotelesa ${ }^{4}$, w tzw. Sumie filozoficznej, Tomasz ujmie mądrość z nieco innego poziomu, dodając do zaprezentowanej już charakterystyki ważne dopowiedzenia. Czytamy: „W człowieku mądrością nazywamy pewną sprawność, która udoskonala umysł w poznawaniu rzeczy najwyższych, a mianowicie rzeczy boskich. Skoro zaś przez sprawność mądrości kształtuje się w naszym intelekcie pewne pojęcie o rzeczach boskich, owo pojęcie umysłowe, będące słowem wewnętrznym, otrzymuje zwykle nazwę mądrości. Otrzymuje zaś tę nazwę zgodnie ze sposobem wyrażania się, w którym działania i ich skutki określamy nazwą sprawności, od której pochodzą" ${ }^{\text {. Mądrość }}$ jest zatem intelektualną sprawnością człowieka, sprawnością udoskonalającą jego poznanie poprzez to, że umożliwia mu poznawanie rzeczy boskich, głównie w sensie Arystotelesowskim, co znaczy, że umożliwia mu poznawanie ostatecznych przyczyn bytu, jest zatem - poznaniem metafizycznym. Warto też zwrócić uwagę, że to pojmowanie mądrości

4 Głównie do fragmentów I.1, 981b28-29 i IV.1 1003a26.

5 Tomasz z Akwinu, Summa contra gentiles, IV.12. Polskie tłumaczenie za: Tomasz z Akwinu, Summa contra gentiles. Prawda wiary chrześcijańskiej, tłum. Z. Włodek, W. Zega, t. 3, Poznań 2009, s. 72 . 
każe nam rozumieć ją na dwóch płaszczyznach: jako sprawność i jako efekt owej sprawności. Inaczej mówiąc: mądrością jest zarówno droga poznania, jak i sam efekt poznania. I jeszcze jedno warto podkreślić: podobnie, jak wcześniej u Awicenny, mądrość lokuje się w obrębie poznania metafizycznego, co zostanie ponownie podkreślone przez Kamińskiego.

Książka Nauka i madrość jest tym dziełem, które bezpośrednio skłoniło lubelskiego filozofa do zajęcia się problemem mądrości, i to przede wszystkim z metodologicznego punktu widzenia. Pisze o tym już na początku swego metodologicznego studium: „J. Maritain przedstawił próbę jednolitej wizji trzech zasadniczych typów wiedzy: naukowej, metafizycznej i mistycznej. Za czynnik jednoczący uznał mądrość, ogarniającą i przenikającą wszelkie rodzaje poznania" ${ }^{\text {. }}$. Maritain, podobnie jak wcześniej Tomasz z Akwinu, dostrzega dwie płaszczyzny ludzkiej działalności: teoretyczną i praktyczną. W nich dostrzega odpowiednie dla tych płaszczyzn cnoty, będące teoretycznymi i praktycznymi. Do porządku teoretycznego czy spekulatywnego należy wiedza, dodajmy: wiedza teoretyczna, do porządku praktycznego należy to, co pozwala rozkoszować się czy wykorzystywać w życiu zdobytą wiedzę ${ }^{7}$. W aspekcie spekulatywnym dostrzegamy nie tylko poznanie, wiedzę czy rozumowanie, ale także mądrość.

Ulokowanie mądrości jako działalności spekulatywnej człowieka można ująć na dwa sposoby, odwołując się do dwóch prac Maritaina, w których pisze on o mądrości. W książce Sztuka i mądrość czytamy: „Inteligencja posiada takie cnoty, których jedynym celem jest wiedza. Te cnoty należą do porządku spekulatywnego. Oto one: zrozumienie zasad, które, skorośmy wysnuli z naszego doświadczenia zmysłowego pojęcia Bytu, Przyczyny, lęku itd., ukazuje nam od razu za przyczyną wrodzonego nam intelektu czynnego - prawdy oczywiste same z siebie, które warunkują całe nasze poznanie; wiedza, która pozwala poznać przez dowodzenie, określając przyczyny; Mądrość, przez którą

6 S. Kamiński, Nauka i filozofia a mądrość, dz. cyt., s. 55.

7 Por. J. Maritain, Sztuka i mądrość, tłum. K. K. Górscy, Warszawa 2001, s. 19-20. 
kontemplujemy przyczyny pierwsze, przy czym umysł obejmuje wszystkie rzeczy w jedności wyższej prostego rzutu oka"8. Cnoty spekulatywne to: zrozumienie zasad, wiedza o przyczynach oraz poznanie pierwszych przyczyn, które daje nam mądrość. Maritain mówi o mądrości jako kontemplowaniu pierwszych przyczyn, oczywiście nie rozumie tego $\mathrm{w}$ sensie praktycznym czy religijnym lub duchowym, lecz teoretycznym, rozumie kontemplację tak, jak ją pojmowali starożytni Grecy, czyli jako najwyższe poznanie, greckie theoria. Odwołując się do greckiego terminu, zawsze w tym momencie mówimy o ogladaniu okiem umystu; wyrażenie to - za Augustynem - będzie używane przez wielu myślicieli średniowiecznej filozofii i teologii'.

Takie rozumienie mądrości rozwijane jest w pracy odwołującej się do nauki i mądrości. Wpierw Maritain wiąże mądrość $\mathrm{z}$ wiedzą. Pisze: „Pojęcie wiedza zawiera trzy znaczenia. W sensie wyższym oznacza ono poznawanie w sposób pewny i trwały, zapewne niewyczerpujący, jeśli nie dokonywany w Bogu, jednakże dostatecznie uzbrojony do uzyskania pewności i zdolny nieskończenie zbliżać się do prawdy. Wówczas mądrość należy rozumieć jako zamykającą się w wiedzy, jako najwyższy stopień wiedzy [... $]^{10}$. Mądrość zatem jest najwyższym poznaniem teoretycznym, które daje nam wiedzę w sposób pewny i trwały. Jest tym poznaniem teoretycznym, które należy pojmować jako ukoronowanie wszelakiej działalności teoretycznej człowieka.

Tak pojmowaną mądrość odróżnia Maritain od dwóch innych sposobów jej pojmowania. $\mathrm{W}$ pierwszym znaczeniu jest ona rozumiana jako przeciwstawienie pewnej wiedzy specjalistycznej. Francuski tomista pisze: „Mądrość jest zatem poznaniem poprzez najwyższe oświecenie; w tym drugim znaczeniu wiedza-nauka oznacza poznanie poprzez

8 J. Maritain, Sztuka i mądrość, dz. cyt., s. 19.

9 Por. Anzelm z Canterbury, Monologion, cap. 1; polska wersja: Anzelm z Canterbury, Monologion. Proslogion, tłum. T. Włodarczyk, Warszawa 1992, rozdz. 1, s. 13.

10 J. Maritain, Nauka i mądrość, dz. cyt., s. 12. Ponieważ ów reprint odwołuje się do języka polskiego okresu międzywojennego, tak w tym cytacie, jak i w każdym innym z tej książki dokonuję pewnego uwspółcześnienia języka. 
szczegóły i uwarunkowania najbliższe i pokrewne"11. Mądrość to poznanie ogólne (dlatego - filozoficzne), a wiedza specjalistyczna - szczegółowe. Jeśli mądrość daje nam przyczyny najwyższe, to wiedza specjalistyczna jedynie najbliższe, konkretne, szczegółowe. Tak pojmowana mądrość jest wreszcie odróżniana od tego, co - w zasadzie - poznaniem już nie jest, bowiem nie ma pewności, gdyż odwołuje się do „pewnego rodzaju poznania płynącego z ciekawości i wykształconego na czystym zamiłowaniu do rzeczy stworzonych, na związaniu i współdziałaniu $\mathrm{z}$ nimi. I nigdy bardziej, jak w tym wypadku, nie przeciwstawia się [taka] wiedza mądrości"12. W tym wypadku, można tak powiedzieć, Maritain odróżnia mądrość od tego, co w sensie potocznym można byłoby nazwać mądrością (co, jak sądzę, także i dziś często nazywane jest mądrością), a co jest tylko pewnym, głębokim wprawdzie, ale jedynie potocznym zamiłowaniem do poznawania. Mądrym jest nie ten, który jedynie posiada jakąś wiedzę o rzeczywistości, ale ten, który tę rzeczywistość rozumie.

Mądrość zatem, o której mówi w swej pracy Maritain, jest najwyższym stopniem wiedzy, wiedzy teoretycznej, a nie praktycznej, wiedzy prowadzącej do poznawania rzeczy boskich, a więc do poznawania pierwszych przyczyn, wiedzy będącej ukoronowaniem ludzkiego procesu poznawania i rozumowania, a co za tym idzie - wiedzy będącej poznaniem metafizycznym, tak jak pojmowali je Arystoteles czy Tomasz z Akwinu (a może jeszcze bardziej Jan Duns Szkot). Jest to mądrość filozoficzna $\mathrm{w}$ pełnym rozumieniu tego słowa ${ }^{13}$. I to jest punkt, $\mathrm{z}$ którego - można chyba tak powiedzieć - wychodzi w swych rozważaniach Kamiński.

\section{Podział mądrości według Stanisława Kamińskiego}

Lubelski filozof i metodolog nie tylko wie, że mądrość jest wiedzą, wiedzą najwyższą, wie również, że samą mądrość można pojmować

11 J. Maritain, Nauka i mądrość, dz. cyt., s. 13.

12 J. Maritain, Nauka i mądrość, dz. cyt., s. 13.

13 Por. J. Maritain, Nauka i mądrość, dz. cyt., s. 20. 
różnorodnie, podobnie jak różnorodnie pojmowany jest w metafizyce byt ${ }^{14}$. To dostrzeżenie różnorodności jest ważnym krokiem w kierunku rozstrzygnięcia pojmowania mądrości w jej relacji do nauki i filozofii, stąd chciałbym więcej miejsca poświęcić nie tylko na zreferowanie tego zagadnienia, ale i na opatrzenie go stosownym komentarzem.

Kamiński zaczyna od specyficznego - bo opartego na etymologicznym pojmowaniu terminów „składających się" na słowo mądrość w języku łacińskim - rozumienia mądrości. Prowadzi go to do pewnego ważkiego filozoficznego rozstrzygnięcia już na samym początku tekstu. Czytamy: „Mądrość (sapientia = sapida scientia, wiedza szczególna, czyli znakomita)"15. Mądrość zatem, jak wynika z tego zapisu, to - po pierwsze - wiedza, po drugie - wiedza szczególna (choć nie w rozumieniu nauk szczegółowych), a po trzecie - wiedza znakomita. Kamiński tym samym wprowadza rozumienie mądrości jako tego, co jest najwyższe.

Teraz dopiero dokonuje pierwszego jej podziału, z punktu widzenia źródeł mądrości. Pisze: „Ze względu na źródła mądrość może być przyrodzona, jeśli osiągana jest naturalnymi siłami poznawczymi, albo nadprzyrodzona, jeśli dochodzi się do niej dzięki pomocy Bożej. W tym drugim przypadku uzyskiwana bywa przez wiarę - fides est initium sapientiae (mądrość formalnie objawiona) lub przez wiarę i rozumowanie (mądrość wirtualnie objawiona, czyli teologiczna) tudzież jako dar Ducha Świętego (nadbudowane na wierze i miłości nadprzyrodzonej doświadczenie kontemplatywne spraw ludzkich i Boskich, czyli mądrość mistyczna) [... $]^{\prime 16}$. Kamiński zatem powiada, że do mądrości człowiek dochodzi po pierwsze wysiłkiem swego własnego przyrodzonego umysłu, a po drugie - $\mathrm{z}$ pomocą nadprzyrodzoną, bądź to $\mathrm{w}$ wyniku wiary w objawienie, bądź to w wyniku wiary i rozumowania, bądź to w wyniku oświecenia łaską Bożą (doświadczenie mistyczne). W pewien sposób $\mathrm{z}$ jednej strony - powiela schemat zaproponowany przez Maritaina,

14 Por. Arystoteles, Metafizyka, VII.1 - 1028a10. „Byt rozumie się wielorako” - polskie tłumaczenie na podstawie: Arystoteles, Metafizyka, tłum. T. Żeleźnik, Lublin 1998, s. 320. Przy wszelkich przywołaniach Arystotelesowskiej Metafizyki korzystam z tego grecko-łacińsko-polskiego wydania.

15 S. Kamiński, Nauka i filozofia a mądrość, dz. cyt., s. 55.

16 S. Kamiński, Nauka i filozofia a mądrość, dz. cyt., s. 55. 
z drugiej strony - w pewien sposób go rozszerza, bowiem mamy tutaj i dochodzenie do mądrości o własnych siłach poznawczych (droga przyrodzona), jak i o własnych siłach poznawczych wychodzących od objawienia (droga nadprzyrodzona $\mathrm{w}$ drugim aspekcie). Z punktu widzenia filozoficznego, a także z punktu widzenia tego tekstu, interesuje nas jedynie ta mądrość, ku której prowadzi droga przyrodzona, czyli przyrodzony rozum.

Mądrość osiągana drogami przyrodzonego rozumu też może być pojmowana różnorodnie. W tej analizie Kamiński prowadzi nas powoli i systematycznie do zamierzonego przez siebie celu. Najpierw wprowadza rozróżnienie na mądrość w sensie potocznym i właściwym. Pisze: „Mądrość przyrodzona zaś dotyczy bądź wyłącznie całości spraw życia codziennego bez odniesienia ich do szerszego kontekstu (sapentia mundana, czyli płynąca z doświadczenia potocznego umiejętność radzenia sobie w życiu, umiejętność «odnalezienia się» wśród rozmaitych okoliczności losu, czy nawet spryt życiowy, przebiegłość i przemyślność), bądź całego świata i człowieka, ujętych w aspekcie najbardziej ostatecznych racji i celów - circa causam altissimam, primam; sub specie aeternitatis (S.Th. I.14.1). Jest to mądrość w sensie ścisłym, najbardziej właściwym, czyli najgłębsze zrozumienie rzeczywistości angażujące zarazem wolę i bezwzględny osąd rzeczywistości (mądrość teoretyczna lub metafizyczna) albo umiejętność stawiania i rozwiązywania tego rodzaju problemów oraz kierowania się taką wiedzą w życiu (mądrość praktyczna)"17.

Mądrość zatem najpierw dzieli się na tę, którą pojmujemy bardziej potocznie, jako pewną zdolność życiową, bo nieodwołującą się do szerszego kontekstu, ani teoretycznego, ani praktycznego, oraz na tę, którą rozumiemy bardziej naukowo, filozoficznie, czy ściśle, gdzie odniesieniem jest jak najpełniejszy kontekst całego świata i człowieka. Dopiero tutaj Kamiński wprowadza podział na mądrość praktyczną, czyli tę, która wprost jest umiejętnością praktycznego rozwiązywania problemów, oraz na mądrość teoretyczną, czyli tę, która daje nam całościowy i bezwzględny osąd rzeczywistości. Można zatem powiedzieć tak: mądrość

17 S. Kamiński, Nauka i filozofia a mądrość, dz. cyt., s. 56. 
w pierwszym rzędzie dzieli się na tę pojmowaną zdroworozsądkowo i tę, pojmowaną naukowo, a ta druga dzieli się na praktyczną i teoretyczną. Można postawić pytanie, czy podział ten jest właściwy, bowiem już w podziale na pojmowanie zdroworozsądkowe i naukowe jest zawarty podział na pojmowanie praktyczne i teoretyczne. Wydaje się jednak, że Kamiński zamierza tutaj zaznaczyć, iż mądrość w całej swej mocy ujawnia się jedynie w porządku teoretycznym, który, poprzez spekulację, jest również porządkiem naukowym.

$\mathrm{Z}$ tak przeprowadzonego podziału (dodajmy: podziału wciąż wstępnego) wynika, że mądrość w sensie ścisłym jest - po pierwsze - mądrością teoretyczną, po drugie - takim działaniem rozumu, które daje nam całościowy i bezwzględny osąd otaczającej człowieka rzeczywistości, po trzecie - tą działalnością, która angażuje również i wolę, bo bez niej nie byłoby przecież „przejścia” od mądrości teoretycznej ku praktycznej. Ważne jest przy tym dostrzeżenie, iż do mądrości w jej aspekcie praktycznym dochodzimy poprzez mądrość w jej aspekcie teoretycznym, a nie odwrotnie. Jednak to pojmowanie mądrości prowadzi Kamińskiego do pewnych filozoficznie ważkich uściśleń.

Tak pojmowana mądrość nie jest, bo być nie może, po pierwsze, zestawem uzyskanych wiadomości o świecie i człowieku. „Mądrość to nie tylko - pisze Kamiński - bogaty układ wszechstronnych informacji, lecz także pewne (bez obawy zbłądzenia) rozumienie kontemplatywne ( $s a-$ pientia comprehendit in se scientiam et intellectum) oraz sprawność poznania najgłębszych racji i ostatecznego celu rzeczywistości (habitus quidam, quo mens nostra perficitur in cogniotione altissimorum et huiusmodi sunt divina - S.G. IV.12)"18. Tutaj, jak sądzę, znajduje się metodologiczny klucz do rozumienia pojęcia mądrości u Kamińskiego.

Mądrość bowiem to nie tyle martwy zestaw posiadanych informacji, to nie tyle kwestia posiadania pewnej wiedzy, ile - powiedziałbym - zestaw dynamiczny, prowadzący do poznania racji ostatecznych poznawanych rzeczy, racji najgłębszych wyjaśniających - by sparafrazować Gabriela Marcela - tajemnicę bytu, racji prowadzących ku ostatecznym 
przyczynom całej rzeczywistości. Chodzi przecież o, powtórzmy, rozumienie rzeczywistości, a nie tylko o posiadanie o niej jakichś wiadomości czy własnego zdania.

Jednak mądrość w sensie ścisłym nie jest także - po drugie - tożsama $\mathrm{z}$ rozsądkiem, choć przecież tak mogłoby się wydawać. Czytamy: „Atoli mądrość w sensie ścisłym nie utożsamia się z rozsądkiem (phronesis), który też bywa nazywany mądrością praktyczną. Rozsądek bowiem jest zdolnością trafnego namysłu nad tym, co dobre albo złe dla życia jednostki oraz opartą na tym namyśle sprawnością działania, czyli dotyczy wyboru nie ostatecznego celu postępowania, lecz doboru środków do niego wiodących" ${ }^{19}$. Ta różnica podkreśla to, że mądrość praktyczna zawsze jest w pewien sposób jednostkowa, ześrodkowana na pewnym jednostkowym praktycznym aspekcie życia człowieka, a mądrość teoretyczna, mądrość w sensie ścisłym, dotyczy fundamentu świata i człowieka, dotyczy tego, co pierwsze.

Raz jeszcze powracając do zaprezentowanego przez Kamińskiego schematu podziału mądrości, do którego wcześniej już się odwoływałem, można teraz skonstruować schemat dwudzielny, w którym w jego pierwszej części będzie podział mądrości ze względu na źródła jej pochodzenia, a w drugiej - ze względu na przedmiot, który leży w jej zasięgu. Całość poprowadzi do pierwszego filozoficznego wniosku dotyczącego mądrości.

Powtórzmy zatem, uściślając: biorąc pod uwagę źródła, z których pochodzi mądrość człowieka, dzielimy ją na mądrość przyrodzoną, będącą efektem naturalnych sił poznawczych ludzkiego rozumu oraz na mądrość nadprzyrodzoną, będącą efektem poznania albo przez wiarę, albo przez wiarę i rozum, albo będącą darem Ducha Świętego (mądrość wlana). Jeśli chodzi o przedmiot, który jest dostępny mądrości, to mądrość przyrodzona, bo ten podział tylko jej dotyczy, dzieli się na mądrość dotyczącą całości spraw życia codziennego pojedynczego człowieka oraz na mądrość dotyczącą całości świata i człowieka w aspekcie ostatecznych racji i celów. I tylko ta ostatnia mądrość jest - wedle 
Kamińskiego - mądrością we właściwym sensie, mądrością w sensie ścisłym. Rozumiejąc ten drugi podział jako podział na mądrość w sensie praktycznym i mądrość w sensie teoretycznym, okazuje się, że mądrość w sensie właściwym jest mądrością teoretyczną, dotyczącą całości świata i człowieka w aspekcie ostatecznych racji i celów. W tym znaczeniu, odwołując się do Tomaszowej definicji metafizyki, jako „naukowo usystematyzowanej mądrości teoretycznej"20, można teraz, za Tomaszem i Kamińskim, określić mądrość jako poznanie metafizyczne prowadzące do poznania ostatecznych racji świata i człowieka.

Prowadzi to do pierwszego filozoficznego wniosku dotyczącego mądrości, który można sformułować poprzez przytoczenie finalnego fragmentu z tekstu Kamińskiego: „Idealnie pojmowana mądrość jest nieodzownym modelem, początkiem i końcem filozofowania (sapientia est caput scientiarum). Całkowicie rozwinięte poznanie metafizyczne nie stanowi jedynie ostatecznościowego wyjaśnienia rzeczywistości, lecz także odkrywając najgłębsze prawdy, nie może wykluczać w następstwie postawy aksjologicznej. Wywołuje więc zaangażowanie - prawdy stają się dobrem (wartością), które należy realizować. Ponadto mądrość filozofii pozwala łączyć sfery poznania naturalnego i nadprzyrodzonego (dirigit omnes scientias). [...] Aby mądrość pełniła w filozofii te wszystkie funkcje, poznanie filozoficzne winno stać się wyjaśnieniem ostatecznościowym oraz aksjologią uzasadnioną najgłębiej ontycznie, a nie tylko gnozeologicznie. Do tego zaś nieodzowna jest rola intuicji intelektualnej jako bezpośredniej, samozwrotnej władzy poznawczej, w niektórych wypadkach nieobalalnie ujmującej swój przedmiot"21.

Warto w tym miejscu wskazać przynajmniej dwa aspekty, które są ważne przy odczytywaniu myśli Kamińskiego. Pierwszy dotyczy pewnego filozoficznego założenia. Jest nim oczywiście pojmowanie filozofii przede wszystkim jako metafizyki, jako teorii bytu, a więc nauki, która poszukuje ostatecznych racji istniejącej rzeczywistości.

20 S. Kamiński, Nauka i filozofia a mądrość, dz. cyt., s. 61. Kamiński odwołuje się tutaj do Tomaszowego komentarza do Metafizyki Arystotelesa - In Meth., XI.1.

21 S. Kamiński, Nauka i filozofia a mądrość, dz. cyt., s. 61. 
W tym sensie mądrość można traktować jako drogę ku odkrywaniu ostatecznych przyczyn rzeczywistości. Drugą płaszczyzną jest wyłaniające się z pierwszej podejście metodologiczne do mądrości. Jeżeli jest ona poznaniem teoretycznym dotyczącym ostatecznych racji istniejącej rzeczywistości, to jak to się dzieje, czyli jakim metodologicznym typem jest ta wiedza. Można powiedzieć, że Kamiński temu aspektowi podporządkowuje całe swe myślenie o mądrości, czyniąc niejako z niego aspekt dominujący.

Mądrość zatem jest poznaniem metafizycznym prowadzącym nas $\mathrm{w}$ głębię bytu, prowadzącym nas ku odkrywaniu ostatecznych racji bytu, a dzieje się to za sprawą intuicji intelektualnej, metafizycznej, której zbadanie da ostateczną odpowiedź dotyczącą natury mądrości w sensie ścisłym.

\section{Poznanie metafizyczne}

Z poznaniem metafizycznym spotykamy się w myśli średniowiecznej w komentarzach do Metafizyki Arystotelesa, tak filozofów arabskich (Awicenna, Awerroes), jak i chrześcijańskich (Tomasz, Duns Szkot, Suarez), jak również w filozofii współczesnej, nawiązującej wprost do filozofii Akwinaty bądź jego uczniów.

Kamiński, jako metodolog metafizyki, zaczyna swe analizy od odniesienia się do wiedzy, jako jednego z zasadniczych elementów ludzkiego poznania. Mówiąc o poznaniu, pamiętamy, że rozumiemy przez nie albo samą czynność poznawczą, czyli pewien naturalny proces człowieka, albo wynik tego procesu w podmiocie. Efektem poznania jako procesu jest wiedza. „Wygodnie jest przyjąć - pisze Kamiński - iż słowo «poznanie» oznacza przede wszystkim proces, a dopiero wtórnie jego wynik. Dla wskazania tego ostatniego używa się bowiem nazwy "wiedza»"22. Proces poznawania jest dla człowieka naturalny i pierwotny, w tym znaczeniu nie można podawać ścisłej definicji poznawania. Poznanie zmierza do zdobycia wiedzy o świecie, jest społecznie nowe,

22 S. Kamiński, Typy ludzkiej wiedzy, w: S. Kamiński, Jak filozofować?, dz. cyt., s. 14. 
czyli twórcze, jest dla podmiotu kształcące ${ }^{23}$. Jednak w tym aspekcie mamy dwie płaszczyzny, zarówno praktyczną i teoretyczną. $Z$ jednej strony, poznanie po prostu pomaga człowiekowi w codziennym życiu, z drugiej strony poprzez poznanie człowiek szuka niepowątpiewalnych podstaw dla swoich przekonań o świecie, szczególnie dla całości systemu informacji o najgłębszych racjach świata oraz sensu ludzkiego życia. $\mathrm{W}$ tym znaczeniu poznanie jest po prostu poszukiwaniem odpowiedzi na najgłębsze pytania, jest zatem fundamentem metafizyki, albo wprost poznanie to jest poznaniem metafizycznym.

Kamiński dokonuje podziału poznania ze względu na poznanie pojmowane jako efekt pewnego procesu. „Ze względu na dopuszczalne źródła i kryteria poznania może być wiedza racjonalna, gdy spełnia kryteria rozumu nastawionego krytycznie, albo irracjonalna, gdy dopuszcza źródła poznania pozaracjonalnego. $Z$ uwagi na genezę i cel przedmiotowy poznania bywa wiedza aprioryczno-spekulatywna i empiryczno-eksplanatywna [...]. Zależnie od ogólnego sposobu uzyskiwania informacji oddzielamy wiedzę systematyczną (planowo zdobywaną) i niesystematyczną (zdobywaną dorywczo). Jeżeli zaś weźmie się pod uwagę związek poznania $\mathrm{z}$ poza poznawczą aktywnością człowieka, wyróżniamy wiedzę czystą oraz zaangażowaną [...] i stosowaną [...]. A wreszcie z uwagi na przedmiot poznania może być wiedza wieloaspektowa albo specjalistyczna. Praktycznie w ciągu wieków ukształtowały się trzy typy wiedzy: potoczna (zdroworozsądkowa), naukowa i filozoficzna (w najszerszym tego słowa znaczeniu). Do tej ostatniej redukuje się najczęściej tak zwany pogląd na świat. Jest to wiedza, która stanowi w zasadzie ostateczną i pełną podstawę uzasadnionego zachowania się człowieka"24. Wiedza zatem, szczególnie ta, która stara się odpowiadać na zasadnicze pytania dotyczące świata i człowieka, jak mówi Kamiński - dotyczące całego świata i człowieka w aspekcie ostatecznych racji i celów - to wiedza zdobywana planowo i systematycznie, wiedza czysta i teoretyczna, sięgająca samej głębi bytu, czyli wiedza filozoficzna. „Filozofia - pisze - łączy się

24 S. Kamiński, Typy ludzkiej wiedzy, dz. cyt., s. 17. 
z poznaniem zdroworozsądkowym, naukowym i z tak zwaną mądrością. Ma dać odpowiedź na wiele pytań istotnych dla całokształtu aktywności człowieka, a szczególnie wskazać, wyjaśnić i uzasadnić ostatecznie, jaki jest sens życia ludzkiego"25.

Wniosek, jaki z tego można wyciągnąć, jest taki, że im bardziej filozofia wiąże się z naukami szczegółowymi, tym mniej zaspokaja te podstawowe intelektualne zainteresowania człowieka, dla których przez niego została wymyślona. Człowiek nie tylko chce znać odpowiedzi na „bieżące" pytania, ale również na pytania bardziej ogólne, sięgające podstaw istnienia świata i jego samego. Stąd taka wiedza, która odpowiada na podstawowe pytania dotyczące całego świata i człowieka w ich ostatecznych przyczynach i celach, to metafizyka, czyli teoria bytu, tożsama, jak chce Tomasz i cała tradycja filozofii klasycznej, z mądrością ${ }^{26}$. Można zatem zaproponować taki schemat: poznawanie $\rightarrow$ wiedza $\rightarrow$ filozofia $\rightarrow$ metafizyka $\rightarrow$ mądrość. Jako wiedza teoretyczna mądrość jest więc ostatecznie uzasadnionym i wyczerpującym rozumieniem świata, jego najgłębszego i ostatecznego porządku oraz sensu życia ${ }^{27}$. Aby można było taką wiedzę (mądrość) osiągnąć, trzeba stosować specyficzną metodę.

W podejściu Kamińskiego obserwujemy wyraźny akcent metodologiczny, ponieważ chce on pojmować poznanie metafizyczne w jego całości, nie tylko w aspekcie jego odnoszenia się do całości świata i człowieka, ale również jako będące całością ludzkiego poznania. Dostrzega też, że jest ono tym poznaniem, które towarzyszy człowiekowi od zawsze. „Już Heraklit ostrzegał - pisze - iż nie wystarczy dużo wiedzieć lub trafnie oceniać ludzi i rzeczy czy też być biegłym w wielu dziedzinach działania, ażeby stać się mądrym. Trzeba w tym celu poznać do głębi i zarazem w sposób zaangażowany [...] istotne i ostateczne pryncypia (przyczyny) wszystkich rzeczy oraz tych ostatnich uporządkowanie

25 S. Kamiński, Typy ludzkiej wiedzy, dz. cyt., s. 23.

26 Por. S. Kamiński, O metodzie filozofii klasycznej, „Roczniki Filozoficzne” 43 (1986) 1, s. 8; M. Rembierz, Jak (powinno się) rozumieć i uprawiać filozofię? O koncepcji filozofii uprawianej przez Stanisława Kamińskiego, w: Stanisław Kamiński, red. K. M. Wolsza, Kraków 2019, s. 32 (Polska Filozofia Chrześcijańska XX wieku).

${ }^{27}$ Por. S. Kamiński, Typy ludzkiej wiedzy, dz. cyt., s. 26. 
wedle fundamentalnych wartości (jak często mawiano - sub specie aeternitatis). Mądrość jest wiedzą najwyższą (Maritain), najbardziej podstawową i ugruntowaną ostatecznie. Usystematyzowaną jej postać stanowi w jakimś stopniu filozofia, a ściślej mówiąc - metafizyka klasyczna, która zajmuje pozycję między nauką a mądrością" ${ }^{28}$. Mądrym zatem nie jest człowiek (powtórzmy to raz jeszcze), który posiada pewien zasób informacji (takiego człowieka moglibyśmy nazwać jedynie inteligentnym), ale mądrym jest ten, którego wiedza jest ostatecznie ugruntowana i sięga ostatecznych przyczyn bytu. W tym znaczeniu jego wiedza jest najwyższą, a on sam jest człowiekiem rozumnym. Do takiej postaci wiedzy dochodzi się poprzez poznanie metafizyczne, będące poznaniem - jak zaznacza Kamiński - intuicyjno-redukcyjnym ${ }^{29}$.

Analiza metody intuicyjno-redukcyjnej zostanie pokazana na dwóch płaszczyznach: metodologicznej (jej zasadnicza charakterystyka) oraz praktycznej (jej sposób funkcjonowania).

Kamiński wychodzi od tego, że nauki szczegółowe, pomimo swych specyficznych metod badawczych, nie potrafią odpowiadać na fundamentalne pytania nie dlatego, że są nieudolne, ale dlatego, że takie pytania leżą poza ich zasięgiem. A z drugiej strony, nauki szczegółowe mają specyficzny dla siebie przedmiot poznania. Wnioskuje zatem, że teoria bytu (metafizyka), dysponująca swym własnym specyficznym przedmiotem, musi też mieć swą własną specyficzną metodę, której nie da się zastąpić którąkolwiek z metod nauk szczegółowych ${ }^{30}$. Dlatego, jak pisze, „tak pojęta teoria bytu obejmuje wszystkie dyscypliny realistycznie pojętej metafizyki i stanowi poznanie filozoficzne jednolite pod względem epistemologiczno-metodologicznym. Poznanie metafizyczne w teorii bytu rozpada się na poszczególne dyscypliny tylko ze względu na odrębny punkt wyjścia (osobny typ przedmiotu danych doświadczenia), a nie na sposób ostatecznej eksplanacji (i przedmiot formalny najbardziej

28 S. Kamiński, Typy ludzkiej wiedzy, dz. cyt., s. 25-26.

29 Por. M. Rembierz, Jak (powinno się) rozumieć i uprawiać filozofię?, dz. cyt., s. 30-31.

30 Por. S. Kamiński, Osobliwość metodologiczna teorii bytu, w: S. Kamiński, Jak filozofować?, dz. cyt., s. 75 . 
teoretycznych tez)" ${ }^{31}$. Badanie polega na poszukiwaniu ostatecznych i nieobalalnych racji w wewnętrznej strukturze bytu. To, o czym tutaj mówimy, to nie pojęcie bytu (jak tego chciał Awicenna, dlatego też został on przywołany), lecz sam byt. Operacja wyjaśniająca w tak pojmowanej metafizyce sprowadza się przede wszystkim do poszukiwania ostatecznych i jedynych racji, które uniesprzeczniają określone stany bytowe, powodujące, że byt w ogóle jest możliwy, nie tylko możliwy do pomyślenia, ale możliwy w sensie ontycznym. Ten proces uwyraźniania aspektu bytowego rzeczywistości dokonuje się poprzez analizę danych zmysłowo-intelektualnego ujmowania świata w świetle bytu jako bytu. „Najbardziej znamiennym wyjaśnieniem metafizycznym jest wskazywanie w oparciu o złożoność wewnętrzną bytu jednej racji ontycznie uniesprzeczniającej dany stan bytowy" ${ }^{32}$. Takie poznanie jest poznaniem koniecznościowym. Można teraz zapytać: jak to działa?

Źródłem takiego poznania nie są ani język, ani żadnego rodzaju formy umysłu (jak sądził m.in. Immanuel Kant), ani przeżycia naszego umysłu (jak uważał m.in. Kartezjusz), lecz sama rzeczywistość, jednak nie rzeczywistość samoistnie bytujących form (jak twierdził Platon), ale rzeczywistość konkretna (Arystoteles). Źródłem takiego poznania jest wreszcie konieczność związana z przyczyną, którą w takim poznaniu odkrywamy $^{33}$. Dokonuje tego intelekt. Jak zaznacza Kamiński, zgodnie z etymologią tego terminu, intelekt od intus legere oznacza „czytać w”, „odczytuje w empirycznie i konkretnie danym stanie rzeczy jakiś prosty, ale ogólny i konieczny, związek"34. Właśnie to odczytywanie koniecznego, a nie jedynie przypadkowego, związku w pewnym konkretnym stanie bytowym jest dziełem tego, co nazywamy poznaniem metafizycznym. Dany jest pewien konkretny byt, a intelekt odczytuje z niego ogólny i konieczny związek, dodajmy: związek wewnętrzny, który ten konkretny stan bytowy uniesprzecznia, nie logicznie, lecz ontycznie. Intelekt czyni

31 S. Kamiński, Osobliwość metodologiczna teorii bytu, dz. cyt., s. 76.

32 S. Kamiński, Osobliwość metodologiczna teorii bytu, Jak filozofować?, dz. cyt., s. 85.

33 Por. S. Kamiński, Czy możliwe są ogólne i konieczne twierdzenia rzeczowe?, w: M. A. Krąpiec, S. Kamiński, Z teorii i metodologii metafizyki, Lublin 1994, s. 308.

34 S. Kamiński, Czy możliwe sq̨ ogólne i konieczne twierdzenia rzeczowe?, dz. cyt., s. 311. 
to w drodze intuicji i redukcji połączonych w jedną metodę poznawczą metafizyki.

Kamiński pokazuje, jak to działa w praktyce. Pisze: „Na podstawie spostrzeżenia trójkąta po dokonaniu abstrakcji ujmuję dzięki intuicji intelektualnej jego naturę pod względem wzajemnych stosunków boków trójkąta tak, że z całą oczywistością przedmiotową (nie subiektywną, bo opieram się bezpośrednio na danym empirycznie trójkącie i dzięki niemu, a ściślej w nim) jawi mi się twierdzenie: suma długości dwóch boków trójkąta jest większa niż długość boku trzeciego"35. Mamy zatem trzy płaszczyzny: (1) rzeczywiście istniejącą rzeczywistość i jej zmysłowe spostrzeżenie (konkretny trójkąt) $\rightarrow$ (2) natura tej rzeczywistości (ujęta w abstrakcji poprzez intuicję intelektualną, trójkąt idealny) $\rightarrow$ (3) ostateczna zasada każdego trójkąta (sformułowana przez intelekt dla każdego możliwego trójkąta w drodze rozumowania lub sądzenia). Punktem wyjścia jest konkretna rzeczywistość, która w ujęciu abstrakcyjnym staje się przedmiotem dla intuicji, ta zaś (od intus legere, czyli „czytać w”) czyta tę zasadę, dzięki której przedmiot ten zostaje ontycznie wyjaśniony, uzyskuje swą ontyczną rację.

Można powiedzieć, że spostrzeżenie zmysłowe konkretnej rzeczy musi zostać wsparte intuicją intelektualną, bowiem dopiero wtedy odkrywamy to, co w bycie jest stałe, konieczne i wyjaśniające w sposób niesprzeczny nie tylko jego naturę, ale i jego istnienie. Poznanie metafizyczne, podobnie jak wcześniej u Awicenny, musi zaczynać się do konkretnie istniejącego bytu, nie prowadzi jednak jak w jego przypadku do pojęcia bytu, nawet najbardziej ogólnego, lecz do odkrycia jego natury i przyczyny. Na tym właśnie polega specyfika tego typu poznania. I dlatego daje ono wiedzę najwyższą, bo wiedzę o przyczynach bytu.

Tak pojmowane poznanie pokazuje, że samo doświadczenie zmysłowe nie jest wystarczające, nie jest też wystarczające poznanie aprioryczne, dopiero poznanie intuicyjno-redukcyjne prowadzi do odkrycia prawdy o rzeczywistości, do odkrycia ostatecznej przyczyny i tego, co tę rzeczywistość metafizycznie uniesprzecznia. Warto zwrócić uwagę, że metoda redukcyjna sama w sobie, stosowana w naukach szczegółowych zawsze

35 S. Kamiński, Czy możliwe są ogólne i konieczne twierdzenia rzeczowe?, dz. cyt., s. 311. 
prowadzi do uprawdopodobnienia, natomiast w metafizyce, wychodząc nie od pojęć czy stanów umysłu, lecz od realnego bytu, prowadzi do konieczności. „Zmysłowe doświadczenie - pisze Kamiński - nie stanowi całej przyczyny poznania zawartego w pryncypiach, lecz stanowi genezę i materię jego, stąd poznanie w pryncypiach rozciąga się poza jakiekolwiek sądy czysto spostrzeżeniowe. Cały proces dochodzenia do pryncypiów odbywa się ostatecznie dzięki władzy, którą po grecku nazwano nous (voũc), po łacinie - intelectus, zaś po polsku - «intuicją intelektualną»" ${ }^{36}$. Tak pojmowana intuicja intelektualna nie jest czymś, co można byłoby porównywać $\mathrm{z}$ intuicją $\mathrm{w}$ sensie potocznym, czy też intuicją mistyczną. Kamiński pisze: „Intuicja metafizyczna jest operacją umysłową poprzedzoną przez abstrakcję i wspartą procesami sądzenia, a nawet rozumowania. Intuicja w metafizyce nie jest czystą, lecz pomieszaną z poznaniem abstrakcyjno-dyskursywnym" ${ }^{\text {"37 }}$. Poprzez zwrócenie uwagi na umysłowy charakter tej intuicji Kamiński chce uniknąć nieporozumienia przyrównującego intuicję do jakichś form poznania pozaumysłowego, do przeczucia, wczucia, odczucia. Jednocześnie mówiąc, że nie jest ona czysta, zwraca uwagę na to, że jej korzenie tkwią w poznawanej rzeczywistości, a nie w samym umyśle. Komentując to, Kamiński napisze: „Akty intuicji intelektualnej (zwłaszcza powtarzalne) odnośnie do prostych relacji koniecznych nie są bowiem ani nagłym olśnieniem (wpadnięciem na pomysł, operacją błyskową), ani też zlepkiem przypadkowych, niepowiązanych ze sobą spostrzeżeń, lecz odpowiednio przygotowanym (zwłaszcza przez dokładne wskazanie przedmiotu poznania i dobrze określone abstrakcje) odczytaniem (intus legere) całościowo i bezpośrednio ujmowanej sytuacji z oczywistością przedmiotową"38. Takie poznanie prowadzi do mądrości.

36 S. Kamiński, O ostatecznych przesłankach w klasycznej filozofii bytu, w: M. A. Krąpiec, S. Kamiński, Z teorii i metodologii metafizyki, dz. cyt., s. 337.

37 S. Kamiński, Próba charakterystyki uzasadniania tez w metafizyce klasycznej, w: M. A. Krąpiec, S. Kamiński, Z teorii i metodologii metafizyki, dz. cyt., s. 382.

38 S. Kamiński, Osobliwość metodologiczna teorii bytu, dz. cyt., s. 84. Na temat tomistycznego pojmowania intuicji intelektualnej zob. E. Morawiec, Intuicja intelektualna w metafizyce ogólnej Jakuba Maritaina. Studium z historii metodologii metafizyki, Warszawa 2008. 


\section{Podsumowanie}

Dzisiejsza rzeczywistość, dość powszechnie już zwana ponowoczesną, coraz rzadziej stara się nie tylko odpowiadać na zasadnicze pytania, jakie stawia sobie człowiek w swym rozumnym życiu, ale nawet nie usiłuje takich pytań formułować. Niejako wzorem starożytnych sceptyków, uważając, iż nie ma możliwości ostatecznego poznania rzeczywistości, dzisiejszy człowiek zbyt szybko rezygnuje z tego, co jest przecież jego istotą - z myślenia. Być może jest tak, że - jak sądził Martin Heidegger jeszcze nie zaczęliśmy myśleć, ale być może jest i tak, że już przestaliśmy myśleć. Przestaliśmy dążyć do mądrości, bo - zwyczajnie - nie rozumiemy, czym jest mądrość. A tego stara się nas nauczyć polski filozof Stanisław Kamiński. Poniższe uwagi to próba zebrania tego, co w tym tekście pochodzi z jego rozważań o istocie mądrości.

Mądrość nie jest jedynie jakimś zasobem wiedzy, który człowiek gromadzi przez lata swej aktywności, nawet, gdyby była to wiedza poparta jego działalnością naukową. Mądrość nie jest jedynie umiejętnością radzenia sobie $\mathrm{w}$ świecie wynikającą $\mathrm{z}$ nagromadzonego doświadczenia nabytego w trakcie długiego życia człowieka. Mądrość to dogłębne poznanie rzeczywistości w jej aspekcie ostatecznych przyczyn i celów. Mądrość to wiedza, wiedza metafizyczna, najbardziej podstawowa, bo najbardziej ugruntowana, sięgająca samych bytowych podstaw. Mądrość to wiedza teoretyczna, będąca ostatecznym i wyczerpującym rozumieniem świata, jego najbardziej zasadniczego, najgłębszego i odwiecznego porządku. Mądrość praktyczna dopiero wtedy jest umiejętnością praktycznego, sprawnego i rozumnego zastosowania mądrości teoretycznej, którą stosujemy w praktyce, w działaniu i kreowaniu naszej postawy wobec świata i drugiego człowieka ${ }^{39}$. W tym miejscu można, na koniec, odwołać się do tytułu zbioru prac metodologicznych i metafilozoficznych Stanisława Kamińskiego, z którego pochodzi jego zasadnicze dzieło

39 Por. S. Kamiński, Od spostrzeżeń do pogladu na świat, w: S. Kamiński, Światopoglad - religia - teologia. Zagadnienia filozoficzne i metodologiczne, red. M. Walczak, A. Bronk, Lublin 1998, s. 26. 
dotyczące mądrości - Nauka i filozofia a mądrość - który brzmi: Jak filozofować? . Na tak postawione tytułowe pytanie Kamiński odpowiada: „tak, by osiągnąć mądrość".

\section{Bibliografia}

Anzelm z Canterbury, Monologion. Proslogion, tłum. T. Włodarczyk, Warszawa 1992.

Arystoteles, Metafizyka, tłum. T. Żeleźnik, Lublin 1998.

Kamiński S., Czy możliwe są ogólne i konieczne twierdzenia rzeczowe?, w: M. A. Krąpiec,

S. Kamiński, Z teorii i metodologii metafizyki, Lublin 1994, s. 303-313.

Kamiński S., Nauka i filozofia a mądrość, w: S. Kamiński, Jak filozofować? Studia z metodologii filozofii klasycznej, red. T. Szubka, Lublin 1989, s. 55-61.

Kamiński S., O metodzie filozofii klasycznej, „Roczniki Filozoficzne”43 (1986) 1, s. 5-20.

Kamiński S., O ostatecznych przesłankach $w$ klasycznej filozofii bytu, w: M. A. Krapiec, S. Kamiński, Z teorii i metodologii metafizyki, Lublin 1994, s. 327-340.

Kamiński S., Od spostrzeżeń do pogladu na świat, w: S. Kamiński, Światopoglad - religia - teologia. Zagadnienia filozoficzne i metodologiczne, red. M. Walczak, A. Bronk, Lublin 1998, s. 13-32.

Kamiński S., Osobliwość metodologiczna teorii bytu, w: S. Kamiński, Jak filozofować? Studia z metodologii filozofii klasycznej, red. T. Szubka, Lublin 1989, s. 71-87.

Kamiński S., Próba charakterystyki uzasadniania tez w metafizyce klasycznej, w: M. A. Krąpiec, S. Kamiński, Z teorii i metodologii metafizyki, Lublin 1994, s. 365-388.

Kamiński S., Typy ludzkiej wiedzy, w: S. Kamiński, Jak filozofować? Studia z metodologii filozofii klasycznej, red. T. Szubka, Lublin 1989, s. 13-32.

Maritain J., Nauka i mądrość, tłum. M. Reutt, Warszawa 2004.

Maritain J., Sztuka i mądrość, tłum. K. K. Górscy, Warszawa 2001.

Morawiec E., Intuicja intelektualna w metafizyce ogólnej Jakuba Maritaina. Studium z historii metodologii metafizyki, Warszawa 2008.

Rembierz M., Jak (powinno się) rozumieć i uprawiać filozofię? O koncepcji filozofii uprawianej przez Stanisława Kamińskiego, w: Stanisław Kamiński, red. K. M. Wolsza, Kraków 2019.

Tomasz z Akwinu, Summa contra gentiles. Prawda wiary chrześcijańskiej, tłum. Z. Włodek, W. Zega, t. 3, Poznań 2009. 
Tomasz z Akwinu, Traktat o Bogu. Summa teologii, kwestie 1-26, tłum. G. Kurylewicz, Z. Nerczuk, M. Olszewski, Kraków 1999.

\section{Abstrakt}

\section{Sapientia - Scientia - Metafisica.}

Uwagi na marginesie tekstu Stanisława Kamińskiego o mądrości

Stanisław Kamiński, polski filozofii i metodolog metafizyki jest autorem bardzo interesującego i inspirującego tekstu o mądrości. W jego filozoficznej analizie odkrywamy bardzo ważne pytanie dotyczące nie tylko samej mądrości, lecz także samego naszego filozoficznego myślenia. Mądrość nie jest jedynie zbiorem jakichś informacji pozyskanych w wyniku ludzkiej działalności w świecie, nawet gdyby taka wiedza była w pewien sposób wspomagana przez naukę. Mądrość nie jest tylko zbiorem ludzkich doświadczeń, wynikających z długiego i owocnego życia człowieka. Mądrość jest wiedzą dogłębną o rzeczywistości, w jej aspekcie odkrywania ostatecznych przyczyn i celów. Mądrość jest wiedzą, wiedzą metafizyczną, najbardziej ugruntowaną, a zatem fundamentalną, ponieważ w niej osiąga się najbardziej zasadniczą podstawę istnienia, realnie istniejący byt, a nie tylko pojęcie bytu. Mądrość jest wiedzą teoretyczną, która jest ostateczną i najpełniejszą wiedzą o świecie, jego wiecznym i najgłębszym porządku. Mądrość praktyczna natomiast jest praktyczną, użyteczną i rozumną aplikacją mądrości teoretycznej, którą wykorzystujemy w praktyce naszego codziennego życia, podejmując działania wobec świata i drugiego człowieka. W tym miejscu można się odwołać do tytułu zbioru metodologicznych i metafilozoficznych studiów Stanisława Kamińskiego, z którego pochodzi omawiany tekst Nauka a filozofia i madrość, a który to tytuł brzmi Jak filozofować?. „Tak, by osiągnąć mądrość" - odpowiedziałby na tytułowe pytanie Kamiński.

\section{Słowa kluczowe}

metafizyka, mądrość, intuicja metafizyczna, Stanisław Kamiński 


\section{Abstract \\ Sapientia - Scientia - Metafisica. Some Remarks on Stanisław Kamiński’s Text on Wisdom}

Stanisław Kamiński, polish philosopher and methodologist of metaphysics, is an author of very interesting and inspiring text on wisdom. In his philosophical analysis we discover very important question not only of wisdom itself but also on our philosophical thinking. Wisdom is not just a set of human knowledge that man accumulates over the years of his activity in the world, even if it was knowledge supported by his scientific activity. Wisdom is not only the ability to cope in the world resulting from accumulated experience, resulting even from a long life of man. Wisdom is an in-depth knowledge of reality in its aspect of ultimate causes and goals. Wisdom is knowledge, metaphysical knowledge, the most basic, because the most grounded, because it reaches the very fundamental basis of existence, the real being, not only a notion of being. Wisdom is theoretical knowledge, which is the final and exhaustive understanding of the world, its most basic, deepest and eternal order. Practical wisdom is then the skill of practical, efficient and intelligent application of theoretical wisdom, which we apply in practice, in acting and creating our attitude towards the world and other people. At this point, one can finally refer to the title of the collection of methodological and metaphilosophical works of Stanisław Kamiński, from which comes his fundamental work on wisdom - Science and philosophy, and wisdom - which reads: How to philosophize? "To achieve wisdom," answers Stanisław Kamiński.

\section{Keywords}

metaphysics, wisdom, metaphysical intuition, Stanisław Kamiński 